\title{
What future(s) for distance education universities? Towards an open network- based approach
}

\section{(¿Qué futuro(s) para las universidades de educación a distancia? Hacia un enfoque abierto basado en la red)}

\author{
António Teixeira \\ Universidade Aberta, UAb \& University of Lisbon, UL (Portugal) \\ Tony Bates \\ Ryerson University - The G. Raymond Chang School of Continuing Education \\ (Canada) \\ José Mota \\ Laboratory of Distance Education and eLearning, Universidade Aberta \\ (Portugal)
}

DOI: http://dx.doi.org/10.5944/ried.22.1.22288

\section{How to reference this article:}

Teixeira, A., Bates, T., \& Mota, J. (2019). What future(s) for distance education universities? Towards an open network-based approach. RIED. Revista Iberoamericana de Educación a Distancia, 22(1), pp. 107-126. doi: http://dx.doi. org/10.5944/ried.22.1.22288

\begin{abstract}
The need for increased scalability, interoperability and flexibility of educational provision is driving the expansion of digital and open learning in higher education. As this movement spreads across institutions worldwide, distance education universities find themselves in a crisis. Technology-enhanced learning is now mainstream in higher education institutions and most have embraced open educational practices as well due to the great impact of MOOCs. In this new fast-growing, chaotic and unstable context, research-based expertise, a dedicated infrastructure and specially-trained staff may no longer seem required for institutions to provide distance and eLearning. Furthermore, new non-institutional non-formal higher education providers of open online or blended learning courses and programmes are emerging as a result of community or special interest group-led initiatives. Far from the days when they stood alone as unique institutions with the unique mission to provide an innovative kind of education, distance education universities are now competing openly with other conventional universities and other educational players. In a time of continuous reduction of public expenditure in higher education, a debate has emerged on the sustainability of
\end{abstract}


these institutions, especially in Europe. In this paper we analyse the new social, economical and technological challenges and opportunities which distance education universities are faced with and discuss the reinterpretation of their typical mission. We also explore existing organisational models and propose a new one based on an open network approach.

Keywords: distance education; open education; higher education; universities; online universities; open universities.

\section{Resumen}

La necesidad de aumentar la escalabilidad, la interoperabilidad y la flexibilidad de la oferta educativa está impulsando la expansión del aprendizaje digital y abierto en la educación superior. A medida que este movimiento se expande por todo el mundo, las universidades de educación a distancia entran en una crisis. El aprendizaje potenciado por la tecnología está ahora diseminado por todas las instituciones y la mayoría también ha adoptado prácticas educativas abiertas cómo consecuencia del gran impacto de los MOOC. En este nuevo contexto de rápido crecimiento, caótico e inestable, de tener expertise basada en la investigación, una infraestructura dedicada y personal especialmente capacitado podrá ya no ser considerado como necesario para que las instituciones puedan ofertar educación a distancia o en línea. Además, van surgiendo nuevos proveedores no institucionales de educación superior no formal, ofertando cursos y programas de aprendizaje abierto en línea o semi-presencial. Lejos de los días en que las universidades de educación a distancia quedaban solas en el sistema educativo con la misión única de proporcionar un tipo innovador de educación para todos, ellas ahora compiten abiertamente con las demás. En un momento de contención del gasto público en educación, surgió en los últimos años un debate sobre la sostenibilidad de estas instituciones, especialmente en Europa. En este trabajo analizamos los nuevos retos y oportunidades sociales, económicas y tecnológicas a los que se enfrentan las universidades de educación a distancia, y discutimos la reinterpretación de su misión. También exploramos los modelos organizacionales existentes y proponemos uno nuevo basado en un enfoque de red abierta.

Palabras clave: educación abierta; enseñanza a distancia; enseñanza superior; universidad; universidad a distancia.

Since the turn of the millennium, the emergence of the global economy and the networked society has transformed significantly our lives and brought new complex challenges to education. It changed how education is perceived, organised and conducted. On the one hand, there is a strong pressure from stakeholders to innovate educational practices. Their aim is to make them more flexible and adjustable to context, which implies a more personalised learning experience. Similarly, they are also pressuring for institutions to resort to innovative competence-based evaluation and certification practices. On the other hand, educational processes need to open and scale up in order not only to reduce costs, but also to become more sustainable 
as they can involve and reach more learners. The introduction of new digital technologies, particularly the Internet and social media, offers up many new ways in which to develop and deliver the knowledge and skills that learners need in the $21^{\text {st }}$ century (Wheeler, 2015).

The combination of these factors has set the scenario for the expansion of digital education across higher education institutions worldwide (Bates, 2015). Technologyenhanced learning is now mainstream in higher education institutions, and most have experienced some form of open education as well due to the great impact of MOOCs.

This scenario would seem to suggest a new dominance of the distance education universities' model within higher education systems. In fact, the massive open universities in Turkey (over 1 million students), Indonesia, South Africa, Pakistan, India, Thailand, Bangladesh and Nigeria continue to draw hundreds of thousands of students each. According to UNESCO, over 21 million students are enrolled in university-level distance education programs in developing countries alone (Bates, 2013). In Europe, estimates suggest 3 million enrolled students. In these regions of the world, dedicated distance education institutions are thriving, in particular, the ones that mix distance education delivery with an open access philosophy. A number of reasons for the situation can be pointed out:

- These institutions achieve massive economies of scale;

- In most cases, the cost for students is much lower than through conventional universities;

- There are just not enough places available in conventional universities;

- Print and, to a lesser extent, broadcasting remain the key media of delivery, more accessible in many of these countries than the Internet;

- They offer in most cases nationally recognized qualifications.

Perhaps surprisingly, though, that is not the case in more economically advanced countries. Although the U.K, Open University has still close to 200,000 students, it has faced severe challenges in the past years because of cuts to funding from government. The same has happened with several other open universities in Europe.

In North America, the state or provincially funded campus-based universities have a long history of distance education. With the advent of online learning, these 'dual-mode' institutions have increased their distance education enrolments much more rapidly than their regular, campus-based student enrolments, while more specialized distance teaching institutions such as Athabasca University and Téluq have seen their enrolments decrease in recent years (Allen \& Seaman, 2014; Bates et al., 2017).

In this new fast-growing, chaotic and unstable context, research-based expertise, a dedicated infrastructure, and specially-trained staff may seem to many as no longer a requirement for operating, even if these characteristics are still needed both by dual- 
mode and alternative providers to Distance Teaching universities. Furthermore, new non-institutional, non-formal higher education providers of open, online or blended learning courses and programmes are emerging as a result of community or special interest group-led initiatives. Also, there has been a new commercialisation of distance education. MOOC platform providers, such as Coursera and FutureLearn, badges in place of degrees or diplomas provided by commercial organisations such as Lynda.com, and 'free' courses and programs, such as those offered by Alison, are all examples. As a result, distance education universities find themselves dealing with an identity crisis.

However, the massification of online learning provision in an unregulated national and cross-border educational market based on the concept of education as a commodity has some obvious downsides. First, there is the risk of decreasing quality standards across the field. As a result of their long-term dominant position as leading institutions in the field, distance education universities have been the reference for quality practices worldwide. In the current context, where leadership is played by institutions new to the field, there is a risk of specialized distance education institutions losing that referential role. As a consequence of the massification and democratisation of the field of practice, expertise-driven learning design and course delivery are also at risk. Last, but not least, it is foreseeable that in a context where provision is dominated by providers not specialized in distance education, there will be an institutional disinvestment in fundamental and applied research in the field of distance education. This can have a negative impact on quality and sustainable innovation, as it will make it difficult for knowledge and innovation to be transferred to teaching and learning practices.

Accreditation of distance higher education programmes and courses plays, therefore, a key role. In accordance, there is a need for all the national accreditation bodies in the European Higher Education Area to adapt the Standards and Guidelines for Quality Assurance - ESG (ENQA, 2015) to online education provision and providers, as suggested in a recent report by ENQA (Huertas et al., 2018). However, we are in a transition period between traditional degrees and qualifications and the building of new forms of accreditation that meet the rapidly changing demands of a digital society and economy. New models will be emerging in the next years.

As soon as the process of recognition and validation of non-formal learning takes off, it will have a major impact not only on distance education universities, but also on entire higher education systems. New education providers will emerge, and traditional (distance and conventional) institutions will have to adapt in order to survive. One critical element will be how they will facilitate the transition to and combination of non-formal and formal learning certification (Teixeira \& Mota, 2014). Universities will have to transform their awards system, making it more modular and personalised. This could represent a competitive advantage for open and distance universities. As such, distance education universities and conventional universities will need to partner in order to build new models of accreditation and 
new qualifications, and to lobby for more flexible transfer of credits and more flexible qualifications.

\section{THE RISK OF UNDIFFERENTIATION}

One of the drivers for the transition of higher education systems towards digital education has been the phenomenon of Massive Open Online Courses - MOOCs (Siemens, 2013). The first MOOC bearing that designation was the "Connectivism and Connective Knowledge" course (CCKo8) offered by Siemens, Downes and Cormier at the University of Manitoba, Canada, in 2008. It was designed according to the connectivist principles of learning (Cormier, 2010; Downes, 2012; Siemens, 2013), as introduced by Siemens (2005). The course drew also on the experiences by Alec Couros ${ }^{1}$ and David Wiley ${ }^{2}$ who, in 2007, decided to open the formal, for-credit courses they were teaching at their institutions to anyone who wanted to take part in them in a not-for-credit, informal way. The term MOOC was coined by Cormier, after registrations for the course went past 2000 participants (Cormier, 2008a). Although this first MOOC set itself in the larger context of Open Education and OER, the concept of a massive online course, albeit with a very different pedagogical approach, became a huge success when Thrun and Norvig opened their "An Introduction to AI" course at Stanford, in the Fall of 2011, to anyone who wanted to take it for free. An impressive 160000 plus people registered for the course.

This unexpected event, coupled with the reputation of the professors and the institution involved, set in motion what would become the educational phenomenon of 2012 (Daniels, 2012; Pappano, 2012; Siemens, 2013). Soon after Thrun created Udacity, and Koller and Ng created a similar company, Coursera. Also, in 2012, MIT announced the partnership with Harvard which established the edX consortium. These new developments were claimed to represent a completely different approach from and even a replacement of 'distance education', particularly since the leading institutions were conventional universities which have previously disdained any online programs.

In the following years since, MOOC provision has grown constantly though. MOOC providers and participants are now spread across all regions of the globe. According to Class Central, the number of MOOCs in 2017 was higher than ever $(9,400)$ and the same applies to MOOC participants (81 million) and providers $(800+)$.

The unprecedented and rapid popularity of MOOCs in the last years has led to an increasing global debate about their quality, involving researchers, practitioners, institutional leaders and learners, while the movement kept thriving. The dissemination of MOOCs, term which is used by many indistinctively to describe also online learning, distance learning and open learning, has challenged distance education provision. This follows on the threat represented initially by the emergence of open educational resources (OERs) and other freely available 
content on the Internet. These materials, such as open textbooks, learning objects, scientific articles, Wikipedia, or video recorded lectures, to give some examples, are available to learners anywhere and at any time. These learners do not have to enrol in a 'dedicated' distance education organisation to obtain access to such resources (Unesco \& CoL, 2011; Weller, 2011).

The same can be stated about blended or hybrid learning, where students can combine campus-based and online learning. With much more flexible opportunities for studying, there could be less demand for full distance learning. Thus, there is now a growing range of competitors for the traditional distance education market. All these developments mean that for on-campus universities, what was previously a specialized activity somewhat on the periphery of an organisation (and, hence, organized and often funded differently) has now moved into the core. There is, therefore, a tendency for distance education to be swallowed up in online learning, OERs, and hybrid learning.

This represents a misconception as open learning, online learning and distance learning are different concepts. MOOCs may be open but if they do not provide recognized qualifications, they do not meet the needs of many students seeking open education. Similarly, OERs will not meet the needs of students who want qualifications but cannot be admitted to institutions that are using these resources. Open textbooks may allow some students who could not afford to attend university to participate, but more likely they will reduce somewhat the debt burden of students who have already been admitted. Lastly, and perhaps the most important implication, open, online and distance learning will each need in most cases a different approach to course design.

Far from the days when they stood alone as unique institutions with a mission to provide an innovative kind of education and, in particular, to widen access to higher education, distance education universities in the more developed countries are now competing with other conventional universities and other educational players. Particularly in North America and Europe, most students who want a university education can access one through a traditional university, provided that they have the necessary educational qualifications. For most students nowadays, with the assistance of grants, loans, scholarships and some part-time work, cost is no longer an insurmountable problem. Limited access, though, to conventional higher education based on lack of recognized academic qualifications remains a barrier for many.

Nevertheless, the dedicated and highly specialized structure and organisation of distance education universities is arguably perceived by government policy makers as somewhat anachronistic, duplicating existing provision. This applies, in particular, to the open universities, whose mission combines the methodological element of distance learning with the philosophical aspect of opening access and participation to all. In times of increased government austerity in many countries, a debate has emerged on the future sustainability of these institutions, especially in Europe. What 
is needed then is a new value proposition based on the unique potential of distance teaching universities.

\section{WHY DO WE STILL NEED DISTANCE EDUCATION UNIVERSITIES?}

There is a massive need for open education worldwide that leads to recognized qualifications, especially when immigrants, older but experienced people, and disadvantaged groups do not fit with typical admission rules and regulations of formal education institutions. This is a new territory for distance education universities, especially in Europe. In addition, lifelong learning will be the life support for many academic departments in the future. However, institutions must be properly prepared and organized to manage these shifts, which come back to institutional leadership and management.

Working students represent the main target group of open universities today, at least in Europe. In the case of the Open University of Portugal, for example, working students account for over $90 \%$ of the total number enrolled in formal programmes. In addition to these, many non-formal learners are also taking advantage of the learning opportunities provided by the open universities. This represents a completely different focus from other higher education institutions.

The market for distance education universities is still largely composed by those who are currently marginalised in our society because of their condition or for lack of opportunities, namely:

- Those who do not have the necessary national or local academic qualifications required for entry to programs at traditional universities;

- Those who have knowledge and skills from work experience and other forms of non-traditional learning that are not accepted for prior credit in traditional institutions;

- Those with special needs;

- Those with a different primary language from the local language;

- Those who have needs for programs, services and methods of delivery that local institutions are unable or unwilling to provide.

Due to their higher institutional flexibility and given social mission, open universities connect more closely with society and have a higher sensibility to emerging societal needs. In the future, however, as traditional higher education institutions open up and start providing digital flexible education at a large scale, open universities will have to go a step further. In that context, open universities will have to introduce more extensively a combination of prior learning recognition with new competence-based and modular forms of learning assessment and certification. Also, they will need to increasingly allow learners to co-design their own courses. In a networked society, open universities will have to resort to a networked 
learning approach. Thus, it will be critical for them to enhance their institutional flexibility by using collective intelligence. As with other kinds of institutions, open universities will have to look at crowdsourcing to scale up their capacity, in the sense of a more distributed teaching and learning process, with the participation of the community (Moore, 2007; Cormier, 2008b; Downes, 2012). One of the most well-known examples of this is the increasing use and reuse of Wikipedia in formal higher education learning activities. But, the volunteer participation of members of the community in the teaching and learning processes is clearly a critical resource to explore further. The way researchers are using crowdsourcing to draw on public knowledge as a means to provide missing historical or other specific details related to communities or families, to complete large-scale tasks, or to solve inherently complex issues, sets the future direction for education.

In this context, there is also a need for institutions dedicated to open education, as there are unique challenges in providing for students who do not meet university or college admission standards. Prior learning assessment and competency-based learning are important approaches to widening access, but they are quite specialized activities. Few traditional universities are ready for such approaches, and students, who come in through 'exceptional' rules or procedures, will always struggle, because the whole institution is not geared towards supporting them. Distance education should be considered as having its own requirements within an integrated approach to student markets, and there will still be an ongoing need for institutions dedicated to open learning.

On a different take, digital technologies are increasingly becoming embedded and distributed in many of the objects and spaces we use and with which we interact (Daanen \& Facer, 2007). Technological convergence is becoming a reality, blurring the frontiers between traditionally separated media - telephone, television, Internet, etc. - and bringing portability and mobility at a large scale.

All higher education institutions need to deal with this fast-changing landscape and provide adequate forms of access, integration and inclusion. It is true that these developments offer new and richer contexts for education and training with, for example, the use of games or gamification strategies, immersive environments or simulations that can enable very realistic learning or performance scenarios (Daanen \& Facer, 2007; Moore, 2007; Downes, 2008) without the dangers inherent to some circumstances. However, as Moore (2007) points out, simply adding technologies to courses does not automatically assure their quality. Using the new technologies to pursue old teaching methods - generally, the content-centered, transmission of knowledge approach that has been the paradigm in traditional universities - does not bring substantial gains. There need to be changes in the pedagogy, in course design, in the role and action of teachers, or in the preparation of resources, to name the most relevant (Mota, 2009).

For Moore (2007), the traditional argument against these changes, i.e. cost, is nothing but an old prejudice; since, in his perspective, distributed teaching 
and learning can overcome financial worries and maintain a high level of quality (Moore, 2007). For Downes (2008), a good level of students' autonomy in the use of materials and resources provided by teachers and/or other experts, and the support of collaborative networks can also help control costs for institutions.

Siemens (2008) believes that it is not even about radical, one-size-fits-all solutions: universities can still provide more structured, more traditional learning experiences for those who prefer it, as has been mostly the norm. It is also not about universities and formal systems of education and accreditation disappearing in the swirl of utopian views of the future of education. According to Siemens (2008), accreditation is still a highly relevant function of universities, but its connection to teaching is weakening. The solution, he says, would be to widen the concept of accreditation, so that universities keep their fundamental role in this domain:

\begin{abstract}
A broad, holistic, accreditation approach is one where the whole person is considered in determining competence. Enlarging the university's current conception of accreditation is an important step forward that ensures universities continue to hold a central role in the knowledge process. (Siemens, 2008)
\end{abstract}

Higher education institutions can evolve and widen or deepen the realm of their activity, becoming organizations that form connections and facilitate relationships, create research opportunities and function as places of discovery and advancement of knowledge (Siemens, 2008).

However, we can also portray a less than optimistic picture of the way in which institutions are reacting to these changes and integrating technology in the teaching and learning process (Bates, 2008). In this view, the degree of innovation and of reflection needed to fuel the necessary changes in the use of technologies is very low. There is a perpetuation of the methods that sought to prepare individuals for an industrial society that is rapidly vanishing, when the current needs are much different. As Bates (2008) suggests: "we need to use technology as an integral part of our teaching and learning activities to prepare learners for a knowledge-based society, where learning prepares for and matches the world of work, leisure and society".

In this respect, distance education universities should be in a better position to deal with the current challenges than traditional universities, not only because of the history and experience they have regarding pedagogical innovation and research in teaching methodologies in higher education, but also given the way in which they were able to successfully adapt to different technological generations. The aforementioned difficulties traditional universities have to integrate new technologies and practices could not be more obvious than what happened to the MOOC concept and the way it was implemented by academics in conventional higher education institutions. Ignoring all the previous research and experience in the field 
of distance education and online learning, the methodologies adopted did not stray too far from the familiar lecture.

However, open and distance teaching universities themselves have struggled to adapt to the pedagogical challenges and opportunities offered by the Internet and social media. In particular, they are hampered by their legacy investments in print, broadcast technologies, and centralized administrative computer systems in an age of cloud computing. The recent turmoil at the UK Open University leading to the forced resignation of its Vice Chancellor over its future direction and the conclusions of the external review of Athabasca University in Canada (Coates, 2017) are just two examples of the challenges faced by open universities in accommodating to pedagogical and technological change.

\section{A NEW VISION AND NEW ORGANISATIONAL MODELS}

In order to address the opportunities identified and to adapt to new markets, social needs and other opportunities, distance education universities will need to demonstrate an increased flexibility. Key areas include:

- Internationalisation and networking amongst peer institutions, forming alliances and allowing for interoperability;

- Unbundling of university services;

- Reorganisation of the academic structure, favouring cross-disciplinary collaboration;

- Refocusing of the university operations around research and innovation in teaching and learning;

- Launching of collaborative labs to transfer knowledge to public administration, companies and NGOs;

- Dissemination of the use and reuse of OERs and open educational practices (OEPs);

- Regular involvement of staff in continuous training and international mobility programs;

- Increased involvement of learners in course co-design processes;

- Implementation of open framework technological infrastructures.

Distance education universities can be defined as specially designed institutions which use an open network organisational framework. They dedicate/commit themselves to advanced research and innovation in technology-enhanced learning, as well as to widening access and participation in higher education for all, independently of context, condition and barriers. Because of their modular and scalable design, distance education universities are particularly prepared for swiftly adjusting to changing societal challenges and needs. 
This is why they must respond to the challenges identified and the opportunities presented above, by introducing a number of shifts in their conceptions, in their vision and strategies, and in their organisational culture. And the first step is to redefine "distance" and "territory", adjusting their mission and organisational culture accordingly, and making them innovative again.

From a strategic perspective, it is critical that distance education universities establish alliances with traditional or conventional higher education institutions, assuring the central role of expertise in driving online education design and delivery. This will be paramount to maintain high quality standards. But, in order to be able to take this role, these institutions must lead research in technology-enhanced and distance learning and improve transfer of innovation from research to pedagogical practice. Only by developing, experimenting and implementing pedagogically enriched online learning design models which enable learners to acquire higher order skills, may distance education institutions fulfil their mission. Another critical aspect, as mentioned previously, relates to the need to develop, experiment and implement innovative competence-based evaluation and certification practices.

The leading position of distance education universities depends on how they scale up activities and assure their sustainability. A key tool is to allow for interoperability of their teaching and learning processes. This implies, in the current context, to disseminate open educational practices and to introduce artificial intelligence, learning analytics and gamification. In accordance, new integrated open learning environments should be designed, with extensive use of artificial intelligence (AI), and explored both with own students and with non-formal external learners (Teixeira \& Mota, 2015).

In order to keep the advantage of expertise, distance education universities need also to continuously train teaching staff and students/learners to operate in enriched open online learning environments. In short, these institutions have to be reengineered in order to transform into continuous learning organisations.

Nevertheless, the demographical, social, political and cultural contexts in which open universities operate in Europe, Canada, Asia or Africa are quite different. As such, understandably open universities already differ in their current business and operation models. Universities can assume different formats. Not all distance or open universities are public state-owned higher education institutions. For the ones which have this form, the transformation of their organisational culture and operation model will depend, significantly, on public policy and on how governments will support them and their mission.

This organisational transformation, however, will also relate to how a given distance education institution decides to embrace an industrial model or a postindustrial (network-based) model. In fact, when we look at emerging new experiences such as the " 42 " university', we have to classify them as open universities even if they are clearly not organised as institutions or traditional companies. In fact, the " 42 " university is a private, nonprofit and tuition-free computer programming school. 
Anyone between 18 and 30 can enroll and the school does not have any professors or issues any diploma or degree. The training is based on peer-to-peer and projectbased learning. All the intellectual property belongs to the students. For these new cases, traditional organisational models do not apply altogether. In our next section we will present a proposal for a post-industrial model which is still institution-based.

\section{A NETWORK-BASED UNBUNDLED MODEL OF DISTANCE EDUCATION UNIVERSITY}

One central point in the deep changes that a networked society has brought about is the way in which knowledge and information are produced, transmitted or distributed in networks that often escape the control of organizations and institutions. The emergence of a participatory culture, in which the locus of power, control and content production is displaced from the traditional producers and providers to those who are sometimes labeled as prosumers - "a combination of producer and consumer that perfectly describes the millions of participants in the Web 2.o revolution", in the words of Riley (2007) - forces, in the field of education, a search for solutions that match these new realities in the form of participatory pedagogies (Askins, 2008; Collis \& Moonen, 2008, referred by Siemens, 2008). In this type of pedagogy, the syllabus is neither closed nor totally defined beforehand, receiving the contribution of learners in its design. Furthermore, the final contents of the learning experience integrate multiple perspectives and approaches, and not only one (the teacher's, the institution's), but also the active creation on the part of the learner (Mota, 2009).

New pedagogical propositions specifically conceptualized for the digital era, such as connectivism (Siemens, 2005) or rhizomatic education (Cormier, 2008b), join other existing pedagogical approaches common in Distance and Online learning, of a constructivist and socio-constructivist nature (Wenger et al., 2011), updated with the new affordances offered by social software (Anderson, 2005; Dalsgaard, 2006). These propositions posit a transition from the models centered in the control of teaching and learning by the institution or the teacher, to models that give a much greater control to learners (Moore, 2007; Siemens, 2013) and emphasize a culture of collaboration and of shared construction of knowledge among independent and autonomous individuals.

The development of digital literacy becomes especially relevant, geared towards supporting the learners' independence and autonomy, and allowing them to pursue their learning in context and according to their needs, in a "just in time" perspective that replaces the traditional "just in case" approach. This process brings together formal and informal learning in models that are based on networks and ecologies where the access to knowledge and learning happen (Siemens, 2006; 2008; Downes, 2008; Teixeira \& Mota, 2015). The ability to define their own goals, identify their 
needs and choose the most adequate options in each particular situation become crucial skills for learners (Siemens, 2006; Moore, 2007; Downes, 2008).

According to Wiley \& Hilton (2009), universities responded to the radical changes technological innovation brought upon human society by increasing connectedness, personalization, participation, and most especially openness, since it is a prerequisite to affordable, large-scale progress in the other areas.

Based on Hagel \& Brown (2005), Wiley \& Hilton (2009) suggest universities will have to rely on "dynamic specialization" strategies, committing to eliminate resources and activities that no longer differentiate them and concentrating on accelerating growth on what truly distinguishes them in society, in order to be or remain successful.

They identify five critical functional areas in university organization. These are:

- $\quad$ Structuring and providing access to content;

- Tutoring and learning support services;

- Curating and providing access to research materials;

- Acting as a hub for social activities; and

- Assessing learning and awarding degrees.

Wiley \& Hilton (2009) expect higher education institutions will focus on developing truly world-class expertise in one or two of these functions and outsource the others.

Wiley \& Hilton's (2009) model of disaggregation of university functions does not stray from the path pioneered by the founding theorists of distance education, who have decomposed the learning process in order to automate its functions and, thereby, scale the reach of educational institutions (Peters, 1988, 1989). Wiley \& Hilton (2009) adopt the same logic of breaking down university functions so that they can scale through massive pooling of resources. However, while both perspectives seek to increase the capacity of institutions to respond to the challenge of widening access by introducing economies of scale and models of industrial organization (nonartisanal), they come from different perspectives (Peters, 2000, 2002).

Peters' (1988) cultural universe is that of an understanding of industrial process in a rational, centralized, hierarchical, sequential, in-line assembly mode that explores the reproductive capacity of unidirectional, one-to-many communication technologies. The content is something watertight that is transmitted in the purest way possible. Any interference during this process is understood as noise, something that degrades the quality of information.

On the contrary, Wiley \& Hilton (2009) fit into a networked, non-hierarchical, deregulated, multidirectional logic of all for all. In this chaotic universe, the industrialization process emerges as an opportunity to scale fragmented content from unplanned and perfectly contextualized random links. The value of the content 
depends on the sheer amount of times it is rebuilt in its dissemination process, that is, it is remixed.

The implementation of such a model has major organizational and management implications (Teixeira, 2012). Innovative universities, as described by Christensen \& Eyring (2011), will have to evolve from a closed environment to an open network one in which data and resources are openly and freely shared with fellow institutions and also the community. This implies a major change in academia and its validation practices, as well as in many other aspects of how higher education institutions operate (Weller, 2011, 2014). However, even the most flexible universities are traditionally very stable organizations, not changing their basic structure and processes over the years. As such, leaders find it very difficult to reengineer them as learning organizations (Senge, 2000). In fact, higher education has historically avoided competitive disruption. According to Christensen \& Eyring (2011), one reason for this past immunity has been the power of prestige in the higher education marketplace, where the quality of the product is hard to measure. In the absence of comparable measures of what universities produce for their students, the wellrespected institutions have a natural advantage. As it is clearly demonstrated in the case of the expansion of distance education and online learning in higher education, a related stabilizing force is also the barrier to disruptive innovation created by the accreditation process, which in the past made conformance to tradition the price of entry to the industry.

Nevertheless, as pointed out above, to facilitate learning of its members and to be able to continuously transform itself as a result of the changing social contexts and development scenarios is critical for the long-term consolidation of institutions in an unstable and highly competitive environment (Christensen \& Eyring, 2011; Senge, 2014). In addition, by unbundling processes and outsourcing services, institutions must contradict an important part of their DNA and tradition which is to continuously grow bigger in size (Christensen \& Eyring, 2011). The implementation of a disruptive innovation-based model as the one presented above requires still, therefore, much debate and further reflection and development.

\section{CONCLUSIONS}

Distance education universities are facing today a social, economical and technological context which presents them with complex challenges as well as exciting new opportunities. Resulting from the combined impact of globalisation and the internet, societies and communities have been calling for increased scalability, interoperability and flexibility of higher education provision. This has led to an enormous expansion of digital and open learning across universities and other higher education institutions worldwide. Yet, distance education universities are finding themselves in a strange paradox. If, on the one hand, technology-enhanced learning has become mainstream in higher education, and most institutions have 
even embraced open educational practices, on the other hand, most of the new competitors have created the illusion that research-based expertise, a dedicated infrastructure and specially-trained staff are no longer an essential requirement for institutions to operate.

In addition, a growing number of non-institutional, non-formal providers are emerging as a result of community or special interest group-led initiatives. In this new scenario, in which every single higher education institution can provide distance education and also open education, a debate has come up among the academic community as well as amongst political decision-makers on the need to maintain dedicated distance education and open education universities.

In this paper, we have demonstrated that dedicated distance education universities are not obsolete and have still an important role to play, albeit different from the past and also with major variations according to each political, economical, social and cultural context. We have analysed their typical mission and verified there is still a lack of especially dedicated institutions whose mission is to assure that higher education opportunities reach every social group at risk. Recent developments across the globe have proven the inequity of higher education provision.

This aspect presents itself differently if we take into consideration less developed and more developed regions. In the first ones, distance education institutions have a regulation role of assuring general access to affordable higher education by all sectors of the population, directed at the major target groups. In the second type of context, the aim is to include marginal groups and rapidly changing scenarios typical of the networked society we live in. This means a higher attention to smaller, more personalised and less visible situations. In addition, dedicated institutions should also be in the front run of response to rapid emerging social needs and complex challenges for which the traditional system is not prepared. For example, situations resulting from critical phenomena, such as social or economical crises, a situation where an urgent, flexible and scalable response is required.

As a result of our research, we claim that, in order to be able to meet these opportunities, however, dedicated distance education universities need to transform and adopt a new organisational approach. One which is more innovative and responsive to a context of contiguous change than Peters' $(1988,1989)$ traditional industrial model, which has been used as reference for most open universities so far. Our proposal uses an open network framework approach in which universities operate as learning organisations (Senge, 2000). It proposes the reengineering of the institutions by disaggregating their functions and unbundling their processes and services, following the suggestion by Wiley \& Hilton (2009) of applying the "dynamic specialization" principle developed by Hagel \& Brown (2005). The implementation of open scholarship (Weller, 2011) and crowdsourcing as well as the increased participation of learners in co-designing and co-assessing their learning experiences is also a key feature. We conclude, however, that such an innovative organizational model highly responsive to environment change is, by definition, 
holistic and organic. This implies that, even if desirable and urgent, its successful implementation must follow further discussion and development.

\section{ACKNOWLEDGEMENTS}

This paper builds upon a research prepared for the EDEN Webinar on the future of the distance education university. The event was organised by the European Distance and E-learning Network, in the framework of the Open Education Week 2018, and held on 5th March, 2018. The conclusions of the paper reflect the discussions held with fellow presenters and participants.

\section{NOTES}

1. EC\&I 831: Social Media \& Open Education - http://eci831.wikispaces.com

2. INST 7150 Introduction to Open Education. Accessible at: http://opencontent.org/ wiki/index.php?title=Intro Open Ed Syllabus

3. See institutional webpage at: https://www.42.us.org

\section{REFERENCES}

Allen, I., \& Seaman, J. (2014). Grade Change: Tracking Online Learning in the United States. Wellesley MA: Babson College/Sloan Foundation.

Anderson, T. (2005). Distance Learning Social software's killer app? Proceedings of the Open \& Distance Learning Association (ODLAA) of Australia, Adelaide. Retrieved from https://www.researchgate.net/ publication/239549918 Distance learning Social software\%27s killer ap on

Bates, T.(A.W.)(Ed.) (2017). Tracking Online Education in Canadian Universities and Colleges. Nova Scotia: Canadian Digital Learning Research Association.

Bates, A.W. (2015). Teaching in a Digital Age: Guidelines for Designing Teaching and Learning. Vancouver BC: Tony Bates Associates Ltd.

Bates. A. W. (2013). Is there a future for distance education? E-learning and distance education resources: Tony's Blog. Retrieved from https://www. tonybates.ca/2013/10/23/is-there-afuture-for-distance-education

Bates, A. W. (2008). The state of e-learning, E-learning and distance education resources: Tony's Blog. Retrieved from http://www.tonybates.ca/2008/12/19/ the-state-of-e-learning-2008

Christensen, C. M., \& Eyring, H. J. (2011). The Innovative University. Changing the DNA of Higher education from inside out. San Francisco: Jossey-Bass.

Coates, K. (2017). Independent ThirdParty Review of Athabasca University. Retrieved from http://www.athabascau. ca/aboutau/documents/third-party/5-12017-third-party-review.pdf

Cormier, D. (2010). What is a MOOC? You Tube. Retrieved from www.youtube.com/ watch?v=eW3gMGqcZQc

Cormier, D. (2008a). The CCKo8 MOOC - Connectivism course, 1/4 way. Dave's Educational Blog. Retrieved from http:// davecormier.com/edblog/2008/10/02/ 
the-ccko8-mooc-connectivism-course14-way

Cormier, D. (2008b). Rhizomatic education: Community as curriculum. Innovate, 4(5). Retrieved from https://nsuworks. nova.edu/innovate/vol4/iss5/2

Daanen, H. \& Facer, K. (2007). 2020 and beyond: Future scenarios for education in the age of new technologies. Bristol: Futurelab. Retrieved from https:// www.nfer.ac.uk/publications/FUTL54/ FUTL54.pdf

Dalsgaard, C. (2006). Social software: e-Learning beyond learning management systems. EURODL, (II). Retrieved from http://www.eurodl.org/materials/ contrib/2006/Christian Dalsgaard.pdf

Daniel, J. (2012). Making Sense of MOOCs: Musings in a Maze of Myth, Paradox and Possibility. Journal of Interactive Media In Education, (3), 18. Retrieved from http://www-jime.open.ac.uk/jime/ article/view/2012-18

Downes, S. (2012). Creating the Connectivist Course. Half an hour. Retrieved from http://halfanhour.blogspot.pt/2012/01/ creating-connectivist-course.html

Downes, S. (2008). The Future of Online Learning: Ten Years On. Half an Hour. Retrieved from https://halfanhour. blogspot.com/2008/11/future-of-onlinelearning-ten-years-on $16 . \mathrm{html}$

European Association for Quality Assurance in Higher Education (ENQA) (2015). Standards and Guidelines for Quality Assurance in the European Higher Education Area (ESG). Brussels, Belgium. Retrieved from http://www.enqa.eu/wpcontent/uploads/2015/11/ESG 2015.pdf

Huertas, E. et al. (2018). Considerations for quality assurance of e-learning provision. Report from the ENQA Working Group VIII on Quality Assurance and e-learning. Occasional Papers 26. Brussels: ENQA. Retrieved from http://www.enqa.eu/indirme/ papers-and-reports/occasional-papers/
Considerations\%20for\%20QA\%20of\%20 e-learning\%20provision.pdf

Moore, M. (2007). Web 2.0: Does it really matter? American Journal of Distance Education, 21(4), 177-183. Retrieved from http://www.informaworld. com/10.1080/08923640701595183

Mota, J. (2009). Da Web 2.o ao e-Learning 2.O: Aprender na Rede (Master Thesis). Retrieved from https://repositorioaberto. uab.pt/bitstream/10400.2/1381/1/ web20 e-learning20 aprender na rede.pdf

Pappano, L. (2012). The Year of the MOOC. New York Times. Retrieved from: www. nytimes.com/2012/11/04/education/ edlife/massive-open-online-courses-aremultiplying-at-a-rapid-pace.html

Peters, O. (2002). Distance Education in Transition. New Trends and Challenges. Oldenburg: Biblotheks - und Informations system der Carl von Ossietzky Universität Oldenburg.

Peters, O. (2000). The transformation of the university into an institution of independent learning. In T. Evans \& D. Nation (Eds.), Changing University Teaching: Reflections on creating educational technologies (10-23) London: Kogan Page.

Peters, O. (1989). The iceberg has not melted: further reflections on the concept of industrialisation and distance teaching, Open Learning , 4(3), 3-8.

Peters, O. (1988). Distance teaching and industrial production: A comparative interpretation in outline. In D. Sewart, D. Keegan \& B. Holmberg (Eds.), Distance education: International perspectives (95-111). Londres/Nova Iorque: CroomHelm/St. Martin's Press.

Riley, D. (2007). The Rise of The Prosumer. TechCrunch. Retrieved from http://www. techcrunch.com/2007/06/15/the-rise-ofthe-prosumer/

Senge, P. (2014). The dance of change: The challenges to sustaining momentum in a 
learning organization (5th edition). New York: Crown Publishing Group.

Senge, P. (2000). The Art and Practice of the Learning Organization, New York: Doubleday.

Siemens, G. (2013). Massive Open Online Courses: Innovation in Education? In R. McGreal, W. Kinuthia \& S. Marshall (Eds.), Open Educational Resources: Innovation, Research and Practice (5-16). Canada: Athabasca University. Retrieved from https://oerknowledgecloud.org/ sites/oerknowledgecloud.org/files/pub PS OER-IRP web.pdf

Siemens, G. (2008). New structures and spaces of learning: The systemic impact of connective knowledge, connectivism, and networked learning. In Web 2.o Meeting. Retrieved from http://elearnspace.org/ Articles/systemic impact.htm

Siemens, G. (2006). Knowing Knowledge. Retrieved from http://www.elearnspace. org/KnowingKnowledge LowRes.pdf

Siemens, G. (2005). Connectivism: A Learning Theory for the Digital Age. International Journal of Instructional Technology and Distance Learning, 2(1), 3-10. Retrieved from http://www.itdl. org/journal/jan 05/articleo1.htm

Teixeira, A. M., \& Mota, J. (2015). A Proposal for the Methodological Design of Collaborative Language MOOCs. In E. Martín-Monje \& E. Bárcena (Eds.), Language MOOCs: Providing Learning, Transcending Boundaries (33-47). Berlin: De Gruyter Open.

Teixeira, A. M., \& Mota, J. (2014). The iMOOC Pedagogical Model: Bridging the gap between non-formal and formal education. In Actas del $V$ Congreso Internacional sobre Calidad y Accesibilidad de la Formación Virtual
- CAFVIR 2014 (512-517). Antigua Guatemala, Guatemala.

Teixeira, A. (2012). Desconstruindo a Universidade: Modelos universitários emergentes mais abertos, flexíveis e sustentáveis. RED. Revista de Educación a Distancia, 32. https://www.um.es/ead/ red/32/teixeira.pdf

Unesco \& CoL (2011). Guidelines for open educational resources (OER) in higher education. Paris: Unesco. Retrieved from http://unesdoc.unesco.org/ images/0021/002136/213605e.pdf

Weller, M. (2014). The Battle for Open: How openness won and why it doesn't feel like victory. London: Ubiquity Press.

Weller, M. (2011). The Digital Scholar: How Technology Is Transforming Scholarly Practice. Basingstoke: Bloomsbury Academic.

Wenger, E., Trayner, B., \& de Laat, M. (2011). Promoting and assessing value creation in communities and networks: $A$ conceptual framework. Rapport 18, Ruud de Moor Centrum, Open Universiteit, The Netherlands. Retrieved from http:// www.leerarchitectuur.nl/wp-content/ uploads/2013/03/Value-creationWenger-De-Laat-Trayner.pdf

Wheeler, S. (2015). Learning with 'e's: Educational theory and practice in the digital age. Bancyfelin, Carmarthen: Crown House Publishing.

Wiley, D., \& Hilton, J. III (2009). Openness, Dynamic Specialization, and the Disaggregated Future of Higher Education. The International Review of Research in Open and Distance Learning, 1O(5), 1-17. Retrieved from http://www. irrodl.org/index.php/irrodl/article/ view/768/1415 


\section{ACADEMIC AND PROFESSIONAL PROFILE OF THE AUTHORS}

António Moreira Teixeira teaches at the Open University of Portugal (Universidade Aberta) where he heads the Department of Education and Distance Learning since 2016. He is also a researcher at the University of Lisbon. He was Pro-Rector for Innovation in Distance Learning at the Open University of Portugal (2006-09) and the President of the European Distance and E-learning Network (2013-16).

E-mail: Antonio.Teixeira@uab.pt

Address:

Universidade Aberta

Palácio Ceia

Rua da Escola Politécnica, 141-147

1269-001 Lisboa

Portugal

Anthony (Tony) Bates is President and CEO of Tony Bates Associates Ltd. He is also Distinguished Visiting Professor in the G. Raymond Chang School of Continuing Education, Ryerson University, Toronto. He was Chair of the International Experts Panel for the Open University of Portugal (2006-09), a member of the World Economic Forum's Global Advisory Council on Technology and Education and a part-time Chair of Research in e-Learning at the Open University of Catalonia, Spain (2003-06).

E-mail: tony.bates@ubc.ca

Address:

Tony Bates Ass.

2777 West 8th Avenue

Vancouver BC

Canada V6K 2B7

José Mota has a degree in English and American Studies from the University of Lisbon and a MEd in eLearning Pedagogy from Universidade Aberta, Portugal. $\mathrm{He}$ is a researcher at the Laboratory of Distance Education and eLearning, [LE@D], Universidade Aberta, with a focus on Personal Learning Environments, Networked Learning and Open Education. He is co-author of the iMOOC - a Pedagogical Model for Massive Open Online Courses.

E-mail: josecmota@gmail.com 
Address:

LEaD - Laboratório de Educação a Distância e eLearning

Palácio Ceia

Rua da Escola Politécnica, 141-147

1269-001 Lisboa

Portugal

Date of receipt: 05/07/2018

Date of acceptance: $16 / 07 / 2018$

Date of layout: 19/08/2018 